\title{
THE EFFECT OF AEROBIC EXERCISE TO THE WEIGHT REDUCTION OF CIVIL SERVANTS WHICH HAVE OVERWEIGHT IN THE EDUCATION OFFICE OF NORTH SUMATERA
}

\author{
${ }^{1}$ Sabar Surbakti, ${ }^{2}$ Dika Nella br. S. \\ Correspondence: State University of Medan, Medan, Indonesia \\ E-mail: surbaktisabar@gmail.com
}

\begin{abstract}
Abstrak
Tujuan penelitian untuk mengetahui apakah ada pengaruh latihan senam aerobic terhadap penurunan berat badan Pegawai Negeri Sipil yang mengalami overweight di Dinas Pendidikan Provinsi Sumatera Utara. Penelitian ini menggunakan metode eksperimen yaitu memberikan perlakuan terhadap sampel. Perlakuan yang diberikan berupa senam aerobik dimana penelitian ini berlangsung selamu 6 minggu. Penelitian ini menggunakan rancangan penelitian pre-test and post-test one group design. Populasi dalam penelitian ini adalah Aparatur Sipil Negara di Dinas Pendidikan Provinsi Sumatera Utara, bagian PMPTK (Pengembangan Mutu Pendidikan Dan Tenaga Kependidikan) yang berjumlah 30 orang, 16 perempuan dan 14 laki-laki, selanjutnya ditentukan sampel penelitian dengan cara proposive sampling yaitu pengambilan sampel menggunakan kriteria tertentu. Berdasarkan kriteria tersebut diperoleh sampel sebanyak 10 orang. Untuk menguji hipotesis dibutuhkan data penelitian yang diperoleh melalui instrumen penelitian. Instrumen/penelitian menggunakan weigh and hight scale (timbangan berat dan tinggi badan), Teknik analisa data yang digunakan adalah statistik uji-t dengan taraf signifikansi a 0,05. Dari hasil analisis data diperoleh penurunan berat badan dengan rata-rata 3,58 dengan nilai t-hitung 13,6 > pada Db 9 dengan taraf kepercayaan 0,05 nilai t-tabel adalah 1.83. t-hitung t-tabel $(13,671,83)$, maka Ho ditolak dan Ha diterima.Maka disimpulkan'bahwa latihan senam aerobik memberikan pengaruh yang signifikan terhadap penurunan berat badan Aparatur Sipil Negara yang mengalami overweight di Dinas Pendidikan Provinsi Sumatera Utara.
\end{abstract}

\section{Kata Kunci: Senam Aerobic, Berat Badan, Overweight}

\begin{abstract}
The purpose of this study was to determine whether there was an effect of aerobic exercise on weight loss of Civil Servants who are overweight in the Education Office of North Sumatra. This study used an experimental method which was giving treatment to the sample. The treatment given was in the form of aerobic exercise where the study was lasted for 6 weeks. This study used a pre-test and post-test one group design research design. The population in this study was the State Civil Apparatus in the Education Office of North Sumatra, the PMPTK (Development of Education Quality and Education Personnel Quality) totaling 30 people, 16 women and 14 min, then the research sample was determined by means
\end{abstract}

PJKR_

http://jurnal.unimed.ac.id/2012/index.php/jpehr 
of a proportional sampling which was sampling using some criteria. Based on these criteria a sample of 10 people was obtained. To test the hypothesis needed research data was obtained through research instruments. The instrument / research used a weight and height scale, the data analysis technique used the t-test statistic with a significance level of 0.05 . From the results of the analysis data obtained weight loss with an average of 3.58 with a t-value of $13.6 \sim$ at $\mathrm{Db} 9$ with a confidence level of 0.05 t-table value was 1.83 . T-count t-table $(13,671,83)$, then Ho was rejected and Ha was accepted. Then it was concluded that aerobic exercise gave a significant effect on weight loss in the State Civil Apparatus which was overweight in the Education Office of North Sumatra.

\section{Keywords: Aerobic Gymnastics, Weight Loss, Overweight}

\section{Introduction}

Overweight is a condition where a person's weight exceeds normal body weight. Rimbawan (2004) Overweight is an ongoing condition which is very closely related to an increased risk of a number of degenerative diseases. Degenerative disease is a disease that arises as a result of the deterioration of the function of body cells from normal to worse and takes place chronically. In terms of health, overweight is very harmful because it can cause various disorders in the body system such as; an increase in cholesterol levels that have an impact on the heart. Meanwhile, when, in the terms of psychology, people who are overweight in general will feel embarrassed by their appearance in the association, this is felt by women. Many advertisements offer very fast weight loss programs, both using tools, medicines, and diets that may be detrimental to the people who use them. Some even want an easy and fast way through the operation of the disposal of body fat, especially the abdomen which can be fatal. Many examples can be seen, people die after liposuction. Bidding programs are always hunted by women, especially mothers who are overweight without regard to health risks.

One of the steps to prevent overweight is to do physical activity (tertiary) and this activity is part of life. Many people need sports, because one's body needs to be maintained so that the body remains healthy, fit and not rigid. So one of the activities carried out is aerobic exercise which is considerably very suitable for weight loss to those who are overweight. Aerobic exercise movements align the upper part of the body and lower body together Aerobic exercises can cause excitement and a sense of enthusiasm when combining basic movements in line Aerobic exercise not only helps a person feel better, but also can lose weight, helps sleep more soundly, relieve stress, and provide fun while doing the exercises.

It also happened to the State Civil Servants (ASN) who served in the Education Office of North Sumatra. Based on the researchers' observations, the type of work they do tended to be less mobile, causing their bodies to easily overweight. Their work from morning to evening was just sitting to complete their tasks. Therefore, only a few calories were used in their daily life, so they held 
aerobic exercises every Friday morning right on the yard of the in the Education Office of North Sumatra. This aerobic exercise can hopefully affect their fitness as well as weight loss for those who are overweight.

Aerobic is one part of gymnastics, Lyne Brick (2002) suggested an aerobic exercise program is one of the best ways for you to lose weight, develop muscle health, and improve quality of life. Aerobic is one of the most popular in fitness exercise. However, aerobics is more fun to do alone or with others. Aerobic exercise not only helps the body feel better, but also helps sleep more soundly, relieves stress, and provides pleasant moments while doing exercise. Purwanto (2011) Aerobic exercise is an exercise that moves all muscles, especially with large muscles with continuous, rhythmic and continuous movements. Aerobic exercise is a series of movements which are chosen deliberately by following the rhythm of the music which is also chosen so as to give birth to certain rhythmic, continuity and duration provisions, Martha Dinata (2007). The benefits of aerobic exercise are its effects on physical fitness, Susiana Candrawati, et al (2016).

The forms of aerobic exercise are carried out with low intensity, so that it can cause the efficiency of the work the body's organ, namely the heart, and lungs and respiratory system. By increasing aerobic capacity, the energy reserves become greater, so that the body will be better able to maintain the physical condition of an activity. That is caused by aerobic exercise, the oxygen intake system takes place continuously and balances with the needs of energy formation. This situation is called the steady state.

According to Lynne Brick (2002) the physical benefits gained from aerobics when aerobic exercise is:

1) Strengthens the Heart; The term of aerobic "with oxygen". During the movement, muscles need oxygen to work efficiently. When muscle swells increase, the body responds by increasing the amount of oxygen sent to the muscles and heart, As a résult, hearto rate and respiratory rate increase to meet their needs. Oxygen is converted to carbon dioxide, and then exhaled. The body sweats, and burns calories and fat. Aerobic increases physical level and helps the body work more efficiently. All things related to heart tissue (heart, blood vessels, and lungs) are the main tissues used by the body during aerobic exercise. The body will adapt to the aerobic exercise program within a few weeks.

2) Strengthens Muscle; In order to become stronger, muscles must be trained beyond their normal load. This is called the principle of overload. To strengthen muscles, they must be trained with high intensity in a short time, using maximum energy and repeatedly. Do not expect additional muscle strength from regular aerobic exercise where the intensity of the exercise is fixed. Will get more strength during intermittent training, while the intensity of the training varies from high intensity training to very low intensity, among 
others by cycling. Low-intensity exercises can be done with muscle endurance exercises using lightweight rubber bands, pipes or barrels.

3) Muscular endurance; Aerobic helps to increase muscular endurance. Muscle endurance is improved by doing a lot of light movements. Aerobic movements such as jumping, lifting knees, and kicking, which are often done, are needed to increase muscle endurance. Aerobic exercises shape the front muscles as well as the back of the body and the sides as well as the hands. Specific aerobic exercises focus on specific muscle groups.

4) Flexibility; Flexibility is the movement around the joint. After completing aerobic exercises, stretching will help to increase flexibility and also help blood circulation return to the heart. The muscles are like rubber bands the stronger the stretch is, the more elastic the rubber is. If you regularly stretch your body after the exercise, you will feel that your muscles and joints will develop.

5) Body composition; The last part of physical health is body composition, which shows a comparison of the collection of muscles, bones, and important fluids in the body compared to fat. On the other hand, professional football players can have more weight than the standard height and weight determined but only have $4 \%$ fat in the body aerobic exercise which will still help to change body composition, increase body fat and build muscle.

Aerobic exercise has advantages, among others; 1) Improve heart function, by increasing heart rate for 20 minutes, 2) Improve lung performance, aerobics help expand lungs and increase stamina and strength, 3) Fight depression, aerobics is known to increase one's mood and the effects of depression, 4) To help you lose weight, help burn fat deposits in the body, 5) Can improve coordination between body and spirit, 6) Can help ward off diabetes. But the lack of aerobic gymnastics does not mean, it's just that these deficiencies will arise when knowledge is not mastered about the basic concepts, the skills to do basic aerobic exercise techniques, and the management of the training.

\section{Method}

This study used an experimental method which was giving treatment to the sample. Does aerobic exercise affect the weight loss of the State Civil Sevants (ASN) who are overweight at the in the Education Office of North Sumatra. The treatment given was in the form of aerobic exercise where the study lasted for 6 weeks. A good aerobic exercise conducted with a frequency of 3-5 times a week with the duration of exercise 20-30 minutes each exercise, Wilmore, Jack \& Costill (1994). The basic consideration for choosing this type of research is;

1) The most adequate way to reach the goal of looking for cause and effect.

2) Free variables are easy to control and control. 
The population in this study was the State Civil Apparatus (ASN) in the in the Education Office of North Sumatra, the PMPTK (development of the quality of education and education staff) totaling 30 people. 16 women and 14 men, then determined the research sample by means of proposive sampling which was sampling using certain criteria. The criteria for taking this sample were:

1) Total Body Mass Index between 25.1-30.0

2) Non-productive age 40-55 years,

3) Not sick.

4) Female sex,

Based on these criteria a sample of 10 people was obtained. This study used a pre-test and post-lest one group design research design, while the research design could be seen in table 1 below:

Table 1. Research design

\begin{tabular}{llll}
\hline Sample & Pre-test & Treatment & Post-test \\
10 people & $\begin{array}{l}\text { Measuring the height and Aerobics } \\
\text { weight of body (IMT) }\end{array}$ & $\begin{array}{l}\text { Measuring the height } \\
\text { exercise }\end{array}$ & $\begin{array}{l}\text { and weight of body } \\
\text { (IMT) }\end{array}$
\end{tabular}

To test the hypothesis needed research data obtained through research instruments. The research instrument used a weigh and high scale (weight and height scales). The data analysis technique used the t-test statistic with a significance level of $\mathrm{a}=0.05$.

\section{Discussion}

The results of the study were answers to the proposed hypothesis, to prove it was conducted by using t-test statistics with the following results;

Table 2. Data on the results of weight loss studies pre-test and post-test

\section{Hypothesis Testing}

\section{Data of Aerobics Exercise}

\begin{tabular}{lll} 
& Pre-test & Post-test \\
\hline Average & 27,85 & 26,63 \\
\hline Standard Deviation & 15,11 & 14,51 \\
\hline Mean Difference & 1.23 & \\
\hline T-count Value & 13,67 & \\
\hline T-table Value & 1.83 & \\
\hline Significant Level & 0,05 & \\
\hline Degree of Freedom & 4
\end{tabular}

From the results of the analysis of the effect of aerobic exercise on weight loss with an average of 3.58 with a t-test value of 13.67 on $\mathrm{Db}-9$ with a confidence level of 0.05 the $t$-table value was 1.83 . Thus $t$-count> $t$-table (13.67> 1.83), then Ho was rejected and $\mathrm{Ha}$ was accepted. So, it was concluded that 
aerobic exercise had a significant effect on weight loss in the State Civil Servants (ASN) who were overweight in the Education Office of North Sumatera.

Based on the results of an experimental study conducted on 10 people who were overweight by doing aerobic exercise for 6 weeks, it was found that there was an effect of exercise on weight loss which was overweight due to an increase in the process of lipolysis. It was the 10 charcoal samples used all of them experienced weight loss, from the whole sample it turned out that they experienced a weight loss of 2 to 3 kilograms. It was concluded that the National Civil Servants' Body Mass Index (ASN) in the Education Office of North Sumatera decreased from 0.82 to 1.78 .

\section{Conclusion}

The conclusion in this study was that through aerobic exercise could reduce body weight of the State Civil Servants (ASN) who was overweight in the Education Office of North Sumatera.

\section{References}

Rimbawan, dan Siagian A, 2004. Indeks Glikemia Pangan. Bandung: Penerbit Swadaya

Dinata, Marta, 2007. Langsing Dengan Aerobik. Jakarta: Cerdas Jaya.

Brick, Lynne, 2002. Bugar Dengan Senam Aerobic. Jakarta: PT Raja grafindo Persada.

Purwanto, 2011. Dampak Senam Aerobik terhadap Daya Tahan Tubuh dan Penyakit. Jurnal Media Ilmu Keolahragaan Indonesia. Volume: 1, Edisi: 1: $1-9$.

Susiana Candrawati dkk, 2016. Senam Aerobik Meningkatkan Daya Tahan Jantung Paru dan Fleksibilitas Aerobic Dance Increase the Cardiorespiratory Endurance and Flexibility. Jurnal Kedokteran Brawijaya. Volume: 29, Edisi: 1: 69-73.

Wilmore, Jack.H \& Costill, David.L, 1994. Physiology of Sport and Exercise.2nd ed. Champaign, Illionis: Human kinetics Published, Inc. 